цінностей у системі освіти України: 3б. наук. пращуь / За заг. Ред.. Г.С.Гребенюка. Харків, 2005. С. 221-225.

2. Рекомендації щодо сторінки для батьків на шкільному інтернетсайті, URL: http://metodcentr10.at.ua/publ/vikhovna_robota/rekomendaciji_shhodo_storinki_dlja_batkiv_na_shkilnomu_internet_sajti/10-1-0-14

DOI https://doi.org/10.30525/978-9934-26-114-5-40

\title{
ЗАСТОСУВАННЯ КОМП'ЮТЕРНИХ ТЕХНОЛОГІЙ ПРИ ВИКЛАДАННІ ХІМІЧНИХ ДИСЦИПЛІН
}

\author{
Chicap O. A. \\ кандидат педагогічних наук, \\ завідувач кафедри природничих дисичиллін \\ Черкаська медична академія \\ м. Черкаси, Україна
}

Впровадження комп'ютерних технологій у освітній процес закладів вищої медичної освіти відбувається надзвичайно швидкими темпами i абсолютно відповідає трендам розвитку цифрового суспільства. Дана тенденція відкриває широкі можливості для підвищення ефективності процесу навчання і сприяе підготовці молоді до майбутньої професійної діяльності у світі, де особливого значення набувають компетентності угалузі високих технологій та цифрові навички фахівців [2, с. 201].

Комп'ютерні технології мають широкі можливості при викладанні дисциплін природничого циклу. На лекціях застосовується інтерактивний мультимедійний програмно-технологічний навчальний комплекс на основі технології SMART Board. Він дозволяє використовувати динамічно-інтерактивну таблицю хімічних елементів Д. І. Менделєєва, що сприяє економії часу та підвищує інформативність. При натискання на потрібний хімічний елемент, на таблиці відкривається розгорнута інформація про нього, можна побачити кількість енергетичних рівнів, розміщення електронів по орбіталях, кількість електронів на зовнішньому енергетичному рівні. Це дає можливість швидко отримати дані для розв'язування задач, визначення валентності, написання окисно-відновних реакцій.

За допомогою ще однієї функції інтерактивного мультимедійного навчального комплексу можна вивчати різноманітне лабораторне 
обладнання, що використовується при проведенні хімічних експериментів. Схематичні зображення хімічних приладів та лабораторного обладнання можна комбінувати між собою, моделюючи майбутній дослід, підбирати оптимальний набір обладнання. За допомогою інтерактивної дошки можна пояснити студентам проведення будь-якого експерименту, його етапи, записати вихідні речовини та продукти реакції, за допомогою кольорів відмітити забарвлення осаду чи зміну кольору індикатора. Такі функції застосовуються при вирішенні розрахункових задач, проблемних завдань, експериментальних задач по способам отримання та способам ідентифікації речовин.

Навчальний комплекс на основі технології SMART Board дає можливість демонструвати наукові відеофільми та відеодосліди. Це доцільно при вивченні природних явищ, промислових процесів та хімічних експериментів значної тривалості. Відеодослід можливо змонтувати і продемонструвати лише основні етапи та акцентувати увагу на явищах, що $є$ найважливішими для розуміння хімічних процесів. Демонстрація відео $\epsilon$ доцільною, якщо у хімічному експерименті використовуються токсичні та небезпечні для здоров'я речовини. Під час перегляду відеодослідів, студенти спостерігають послідовність операцій під час хімічного експерименту, навчаються правильно користуватися лабораторним обладнанням, дотримуватися техніки безпеки в хімічній лабораторії. Перегляд таких навчальних фільмів $€$ актуальним на практичних заняттях 3 аналітичної, токсикологічної, біологічної хімії. Так, наприклад, при вивченні тем з кількісного аналізу перед тим, як проводити титрування електрометричним методом за допомогою $\mathrm{pH}$-метру або визначати концентрацію методом фотоколориметрії, студенти переглядають інструктивні відеоматеріали по користуванню $\mathrm{pH}$-метром та фотоколориметром. Оскільки в навчальній лабораторії $є$ лише дві чи три моделі даних приладів, то за допомогою навчальних відеофільмів можна ознайомити студентів з різними моделями $\mathrm{pH}$-метрів, фотоколориметрів, рефрактометрів та інших приладів.

За допомогою інтерактивної дошки можна продемонструвати 3D моделі хімічних речовин. Така функція актуальна при вивченні органічної хімії, зокрема поняття про гібридизацію атомів Карбону, будову молекул складних органічних речовин. 3D моделі можна обертати під будь-яким кутом, демонструючи порядок розташування атомів, відстань між ними, типи зв'язків між атомами, кути між зв'язками.

Найбільш ефективною 3 комп'ютерних технологій на практичних заняттях з хімічних дисциплін $\epsilon$ цифрова лабораторія «Einstein». Набір датчиків цифрової лабораторії дозволяє проводити широкий спектр 
досліджень 3 дисциплін «Медична хімія», «Фізична та колоїдна хімія», «Неорганічна хімія», «Аналітична хімія», «Токсикологічна хімія». За допомогою відповідних програм, що встановлені на комп'ютері, результати досліджень виміряні датчиками цифрової лабораторії, можна відображати у вигляді таблиць чи графіків, зберігати їх у пам'яті комп'ютера та порівнювати між собою. Крім можливості зберігати результати експерименту, лабораторія «Einstein» дозволяє за обмежений час проводити більше дослідів та отримувати результати високої точності. Одночасно можна підключити декілька датчиків та замірювати різні параметри, що змінюються під час експерименту, що дає можливість встановлювати їх взаємозв'язок, залежність одного параметра від іншого.

Документ-камеру можна використовувати для демонстрації дослідів на інтерактивній дошці у режимі реального часу. Виконувати експеримент на своєму робочому місці може як викладач, так і студент, а інші студенти групи спостерігатимуть за цим на дошці. При цьому можливо відкривати не тільки вікно відео, а і вікна графіків та таблиць i спостерігати за цифровими значеннями експерименту. За допомогою документ-камери збільшують та демонструють на інтерактивній дошці об’єкти невеликих розмірів. При вивченні біологічної хімії, а саме тем 3 біохімії печінки, крові, м'язевої, сполучної тканин таким чином виводять на дошку бланки результатів обстежень пацієнтів, що мають патології обміну речовин та пояснюють відхилення від норми.

Інший варіант використання документ-камери - зйомка відеодослідів. Це ефективно використовувати у гуртковій роботі. Під час такої діяльності студенти можуть проявити свої творчі здібності: розробити та відзняти всі етапи досліду, записати пояснення до кожного етапу, змонтувати відеометріали так, щоб вони найкраще відображали суть i результати дослідження. Відеоматеріали створені студентами у майбутньому можна використовувати на лекціях, практичних заняттях, при презентації досліджень на науково-практичних конференція та відкритих засіданнях гуртка.

Цифрові технології, комп’ютеризація - це сучасне та майбутнє усіх галузей нашого життя, у тому числі і професійної діяльності медика чи фармацевта. Сучасне медицини пов'язане із застосуванням комп'ютерної техніки при проведенні обстежень, діагностики, лікування. Активно використовуються системи цифрової рентгенографії, МРТ та УЗД апарати, комп'ютерні томографи, цифрові мікроскопи, проведення променевої терапії з мікропроцесорним управлінням. Майбутнє медицини базується на досягненні цифрових технологій охорони здоров'я, таких як штучний інтелект, технологія виртуальної реальності 160 
(VR / AR), 3D-друк, робототехніка, нанотехнології [1]. Такі тенденції вимагають, щоб майбутні медики та фармацевти починали опановувати сучасні комп'ютерні та інформаційні технології вже на перших курсах під час вивчення природничих дисциплін. Це сприятиме формуванню у студентів світогляду відповідно до сучасних реалій, де навчання, наука, медицина і комп'ютеризація є нерозривними складовими.

\title{
Література:
}

1. Соколенко Л. Ф., Линник С. О. Впровадження засобів цифрового управління в сфері охорони здоров'я. URL: http://www.dy.nayka.com.ua/ pdf/8_2020/55.pdf (дата звернення: 03.07.2021).

2. Струтинська О. В., Умрик М. А. Сучасні освітні тренди в умовах розвитку цифрового суспільства. URL: http://www.innovpedagogy.od.ua/ archives/2020/26/42.pdf (дата звернення: 02.07.2021).

DOI https://doi.org/10.30525/978-9934-26-114-5-41

\section{ЗДОБУТКИ В ЦАРИНІ МЕТОДИКИ НАВЧАННЯ ЛІТЕРАТУРИ В ПЕРІОД КІНЦЯ ХІХ - ПОЧАТКУ ХХ СТОЛІТТЯ}

\author{
Степаненко О. К. \\ кандидат філологічних наук, доцент, \\ докторант кафедри методики викладання світової літератури \\ Національний педагогічний університет імені М. П. Драгоманова \\ м. Київ, Украӥна
}

Методична теорія наших днів - це в першу чергу узагальнення досвіду викладання літератури в сучасній школі. Вона враховує i передовий досвід минулого, спирається на цінні напрацювання педагогів-словесників, враховує уроки та розвиває кращі традиції літературної освіти. Історія методичної думки на наших теренах нероздільно пов'язана із суспільним розвитком, становленням літератури, з іменами видатних діячів науки й культури, літераторів і педагогів, перших авторів наукових праць, навчальних посібників, статей 3 проблем теорії та історії словесності, з питань навчання та виховання.

В історії методики викладання літератури XIX століття яскраво виявилися три течії - логіко-стилістична, освітньо-виховна і етикоестетична, які розширювалися, поглиблювалися та інтегрували на наступних етапах розвитку науки і відіграли важливу роль 